Original Contribution

\title{
EVALUATION OF CAMEL RUMEN CONTENT AS A FEED FOR BROILER CHICKENS
}

\author{
O. J. Makinde ${ }^{1^{*}}$, A. M. Abdullahi ${ }^{1}$, G. Mohammed ${ }^{2}$ \\ ${ }^{1}$ Department of Animal Science, Federal University, Gashua, Nigeria \\ ${ }^{2}$ Department of Animal Science, University of Maiduguri, Nigeria
}

\begin{abstract}
This study was carried out to evaluate the growth performance, carcass characteristics and haematological parameters of broiler chickens fed diets containing graded levels of Camel Rumen Content (CRC) as a replacement for maize and groundnut cake. CRC was included in the diets of broilers at $0,5,10,15$, and $20 \%$ and designated as TI, T2, T3, T4 and T5 respectively. Five dietary treatments were formulated. One hundred and fifty day-old broiler chicks (Anak breed) were randomly allotted to five treatments replicated thrice with 10 chicks per replicate in a completely randomized design. Feed and water were supplied ad libitum for 28 days. Means of body weight gain, feed intake and feed conversion ratio of broilers fed the control diet, 5\%, 10\% and $15 \%$ CRC diets were significantly $(\mathrm{P}<0.05)$ better than those fed $20 \%$ CRC diet. Carcass characteristics of birds followed similar pattern with the growth performance. There were no significant $(\mathrm{P}>0.05)$ differences in the haematological parameters measured except haemoglobin and mean corpuscular haemoglobin concentration. Also, basophils and monocytes were not significantly $(\mathrm{P}>0.05)$ different among the differential counts measured. It was concluded that up to $15 \% \mathrm{CRC}$ can be included in broilers diet to replace maize and groundnut cake without adverse effect on the performance of birds.
\end{abstract}

Key words: Broiler chickens, camel rumen content, performance, haematology, carcass

\section{INTRODUCTION}

In Nigeria, the supply of protein from animal origin such as egg, meat and milk falls short of demand because of the rapid increase in human population and the competition for feedstuff between the increase human population and livestock sector. Most Nigerians are poorly fed and are suffering from malnutrition due to lack of protein of animal protein (1). High cost and scarcity of conventional feedstuffs constitute major problems facing commercial livestock production in developing and underdeveloped countries. Unconventional feedstuffs, which are usually of no feeding value to humans, are much cheaper. One of such is abattoir waste particularly rumen contents (RC). Rumen contents are gotten from the rumen of camels, buffalos, cattle, sheep and goats etc. In Nigeria, ruminant animals are the major source of animal protein with large numbers being slaughtered daily resulting in concomitant higher production of RC. Previous studies have generally indicated that dried rumen contents (DRC) contained substantial amount of crude

\footnotetext{
*Correspondence to: $O . J$. Makinde, Department of Animal Science, Federal University, Gashua, Nigeria,E-mail: johyinmak@yahoo.com
}

protein (CP) and utilizable energy for ruminants (2). Rumen content is rich in microbial protein $(3,4)$ and contains digested feed at different stages of degradation, saliva (making up the rumen liquor), microorganisms and the products of their metabolic activities such as proteins, peptides, amino acids, lipids, vitamins and volatile fatty acids. Despite these qualities, the nutritional potentials of $\mathrm{RC}$ in concentrate based diets remain currently under-researched in Nigeria. The present study was designed to determine the effects of feeding different levels of Camel Rumen Content on the growth performance, carcass characteristics and haematological parameters of broiler chickens.

\section{MATERIALS AND METHODS Experimental site}

The research was conducted at the Department of Animal Science Teaching and Research Farm, University of Maiduguri. The research area lies between latitude $105^{\circ}$ North and longitude $30.05^{\circ}$ East and is on latitude of $364 \mathrm{~m}$ above sea level (5). Mean relative humidity ranges from $30-50 \%$ with a maximum of about $90 \%$ in the month of August (6). The research area falls within the 
semi arid zone of West Africa characterized by short rainfall ranging from $300 \mathrm{~mm}-700 \mathrm{~mm}$ per annum and falls mostly between May and October with temperature ranging from $33^{\circ} \mathrm{C}$ $44^{0} \mathrm{C}(5)$.

\section{Management of Experimental birds}

One hundred and fifty (150) one day old chicks were purchased from a reputable hatchery in Enugu State and used for the research. The chicks were randomly alloted to five (5) treatments in groups of 30 birds per treatment. Each treatment was replicated thrice with 10 birds per replicate in a completely randomized design. The birds were raised in a deep litter system for 28 days. Feed and water were supplied ad libitum.

\section{Collection and Processing of camel rumen content}

Camel rumen contents were collected from Maiduguri abattoir, Borno State. After slaughtering, the rumen was split open with aid of sharp butcher's knife and the contents emptied into a polythene bags. It was allowed to drain in the sack. After draining, the rumen contents were then spread on a cemented floor and allowed to sundry while turning was done between 3-4 hours interval until the moisture content was below $15 \%$ after $4-5$ days of sun drying. The dried rumen content was then ground and incorporated into the diets.

\section{Experimental diets}

Five experimental diets were formulated using the following ingredients: maize, wheat offal, bone meal, groundnut cake, fish meal, common salt, premixes and dried camel rumen content as shown in Table 2. Camel rumen content serves as a test ingredient to replace maize and groundnut cake at $0,5,10,15$, and $20 \%$ in diets $1,2,3,4$, and 5 respectively.

Table 1. Proximate composition of Camel Rumen content

\begin{tabular}{ll}
\hline Nutrients, \% & Composition \\
\hline Dry matter & 93.70 \\
Crude protein & 23.70 \\
Crude fibre & 28.10 \\
Ether extract & 3.00 \\
Ash & 12.00 \\
Nitrogen free extract & 56.90 \\
Metabolizable energy, Kg/kcalME & 2070.85 \\
\hline
\end{tabular}

Table 2. Gross composition of Experimental diets

\begin{tabular}{llllll}
\hline Ingredients, Kg & $\mathbf{0 \%}$ CRC & $\mathbf{5 \%} \mathbf{C R C}$ & $\mathbf{1 0 \%} \mathbf{C R C}$ & $\mathbf{1 5 \%} \mathbf{C R C}$ & $\mathbf{2 0 \%}$ CRC \\
\hline Maize & 56.29 & 53.67 & 51.04 & 48.40 & 45.78 \\
Groundnut cake & 24.96 & 22.58 & 20.21 & 17.85 & 15.47 \\
CRC & 0.00 & 5.00 & 10.00 & 15.00 & 20.00 \\
Wheat offal & 12.00 & 12.00 & 12.00 & 12.00 & 12.00 \\
Fish meal & 3.00 & 3.00 & 3.00 & 3.00 & 3.00 \\
Bone meal & 3.00 & 3.00 & 3.00 & 3.00 & 3.00 \\
Salt & 0.30 & 0.30 & 0.30 & 0.30 & 0.30 \\
*Premix & 0.25 & 0.25 & 0.25 & 0.25 & 0.25 \\
Methionine & 0.10 & 0.10 & 0.10 & 0.10 & 0.10 \\
Lysine & 0.10 & 0.10 & 0.10 & 0.10 & 0.10 \\
\hline Total & $\mathbf{1 0 0 . 0 0}$ & $\mathbf{1 0 0 . 0 0}$ & $\mathbf{1 0 0 . 0 0}$ & $\mathbf{1 0 0 . 0 0}$ & $\mathbf{1 0 0 . 0 0}$ \\
\hline Proximate Composition & $\mathbf{\%}$ & & & & 89.30 \\
Dry matter & 89.20 & 87.90 & 90.00 & 87.30 & 21.90 \\
Crude protein & 21.90 & 22.00 & 21.10 & 21.00 & 8.62 \\
Crude fibre & 3.63 & 4.49 & 6.13 & 7.38 & 2.50 \\
Ether extract & 3.00 & 3.50 & 2.00 & 2.50 & 3.00 \\
Ash & 2.50 & 2.50 & 3.00 & 3.00 & 51.28 \\
NFE & 56.17 & 53.01 & 55.27 & 51.42 & 2907.24 \\
M.E (Kcal/kgME) & 3121.34 & 3053.36 & 3015.79 & 2934.91 &
\end{tabular}

CRC - Camel Rumen Content. NFE= Nitrogen free extract.ME=Metabolizable energy. *Premix in diets provided per kg: Vit. A 10000 IU, Vit. B 2000 IU, Vit. E 13000 IU, Vit. K 1500mg, Vit. B12 10mg, Riboflavin 5000mg, Pyridoxine 1300mg, Thiamine 1300mg, Panthothenic acid 8000mg, Nicotinic acid 28000mg, Folic acid 500mg, Biotin 40mg, Copper 7000mg, Manganese $48000 \mathrm{mg}$, Iron 58000mg, Zin c 58000mg, Selenium 120mg, Iodine 60mg, Cobalt 300mg, Choline 27500mg

\section{Performance data}

The amount of feed given and left over was recorded on daily basis and it was used to calculate the feed intake. Before the commencement of the experiment, the initial weight of the birds were taken and the birds were weighed weekly thereafter to obtain weekly weight gain. Feed intake and weight 
recorded were used to calculate feed conversion ratio (FCR) using the formula below.

Feed conversion ratio (FCR) $=$ feed intake/weight gain

\section{Blood collection}

At the end of the study period, $5 \mathrm{ml}$ of blood was collected from three birds per treatment through the wing vein and put into bottles containing Ethylene Diaminetetra- acetic Acid (EDTA) to determine the haematological indices which include packed cell volume (PCV), haemoglobin concentration $(\mathrm{Hb})$, red blood cell (RBC) count or erythrocytes and white blood cell (WBC) count or leucocytes and differential counts. Others such as mean corpuscular haemoglobin (MCH), mean corpuscular volume (MCV) and mean corpuscular haemoglobin concentration (MCHC) were obtained by calculation according to standard formulae $(7,8)$ as shown below:

$$
\begin{aligned}
& \underline{\mathrm{PCV} \times 10} \\
& \mathrm{MCV}=\mathrm{RBC} \text { count }\left(\text { in } 10^{6} / \mathrm{mm}^{3}\right) \\
& \mathrm{MCH}=\frac{\underline{\mathrm{Hb}(\mathrm{g} / \mathrm{dl}) \times 10}}{\mathrm{RBC}\left(\mathrm{in} 10^{6} / \mathrm{mm}^{3}\right.} \\
& \mathrm{MCHC}=\frac{\mathrm{Hb}(\mathrm{g} / \mathrm{dl}) \times 100}{\mathrm{PCV} \%}
\end{aligned}
$$

\section{Carcass and Organs Weight determination}

At the end of the study, two birds per replicate were selected at random and starved for about $12 \mathrm{~h}$ to empty the crops. They were then slaughtered, scalded, plucked and eviscerated. The carcass and internal organs (liver, heart, kidney, gizzard and intestines) were removed, weighed and expressed as a percentage of live weight.

\section{Chemical analysis}

Proximate composition of CRC and experimental diets were analysed using the methods described by (9).

\section{Statistical analysis}

Data collected were subjected to analysis of Variance using SAS software (10) while significant means were separated with Duncan multiple range test at $5 \%$ level of significance.

\section{RESULTS AND DISCUSSION \\ Proximate Composition of the Experimental Diets}

The result of the proximate composition of the camel rumen content used in this study is presented on Table 1. The result shows that camel rumen content (CRC) contained $23.70 \%$ crude protein, $28.10 \%$ crude fibre, $3.00 \%$ Ether extract, Ash, $33.70 \%$ NFE and $2316.25 \mathrm{Kcal} / \mathrm{kg} \mathrm{ME}$. This result differs from the report of (4) who reported that dried bovine rumen digesta contains $18.20 \%$ moisture, $15.30 \%$ crude fibre, $18.52 \%$ crude protein, $7.60 \%$ ash, $8.79 \%$ ether extract and $38.39 \%$ NFE. (11) Gave the following as the composition of bovine rumen content: moisture $9.69 \%$, crude fibre $39.95 \%$, crude protein $9.82 \%$, fat $1.10 \%$, NFE $30.55 \%$ and Ash $18.58 \%$. Therefore, CRC provides a richer source of nutrients suitable of exploitation for use as possible feed ingredient.

\section{Growth Performance}

The performance of broiler starter chickens fed graded level of camel rumen content (CRC) is presented in Table 3. The daily feed intake, daily weight gain and feed conversion ratio were significantly $(\mathrm{P}<0.05)$ different among the treatment groups. Birds fed $20 \%$ CRC consumed significantly $(\mathrm{P}<0.05)$ more feed than birds fed other diets. The variations in the feed intake of birds across the dietary groups may be attributed to the differences in the fibre content of the diets. The diet with $20 \%$ CRC contained about $8.62 \%$ crude fibre. Some authors $(12,13)$ had earlier reported that feed intake of birds increased with increased levels of fibre in diet because the birds eat to meet their energy requirement. Similarly, the observation in this study agrees with the report of (12) who reported that although birds fed diets containing dried rumen digesta recorded better feed intake, feed cost per kilogramme body weight gain, feed conversion ratio and relative organ weights than those fed the control diet, only feed intake of the birds was significant $(\mathrm{P}<0.05)$. Daily weight gain of birds fed $0 \%$ CRC, $5 \%$ CRC, $10 \%$ CRC and 15 $\%$ CRC were similar $(\mathrm{P}>0.05)$ and higher $(\mathrm{P}<0.05)$ than birds fed $20 \% \mathrm{CRC}$ diet. This means that inclusion of CRC up to $20 \%$ in the diets of broilers affect the daily weight gain of the birds. $(14,15)$ fed rumen content to broilers and revealed that there was a decrease in daily weight gain of birds as the levels of CRC increased in the diets. The feed conversion ratio of birds fed $0 \%$ CRC, $5 \%$ CRC, 10 $\%$ CRC and $15 \%$ CRC were similar $(\mathrm{P}<0.05)$ and better than those fed $20 \% \mathrm{CRC}$ diet. (16) observed significant differences in feed conversion ratio of broiler chickens fed sundried rumen content blood meal diets. (4) however reported no significant difference in the feed conversion ratio of birds fed graded levels of dried rumen digesta. 
MAKINDE O. J., et al.

Table 3. Performance of broiler chickens fed camel rumen content (0-8weeks)

\begin{tabular}{lllllll}
\hline Parameters & $\mathbf{0 \% C R C}$ & $\mathbf{5 \% C R C}$ & $\mathbf{1 0 \%}$ CRC & $\mathbf{1 5 \% C R C}$ & $\mathbf{2 0 \%}$ CRC & SEM \\
\hline $\begin{array}{l}\text { Initial wt, g/b } \\
\text { Final wt, g/b }\end{array}$ & 34.34 & 35.19 & 34.35 & 35.82 & 34.50 & 0.74 \\
$\begin{array}{l}\text { Av. Wt gain, } \\
\text { g/b }\end{array}$ & $2047.76^{\mathrm{a}}$ & $2057.10^{\mathrm{a}}$ & $1994.60^{\mathrm{a}}$ & $1969.00^{\mathrm{a}}$ & $1646.70^{\mathrm{b}}$ & 72.55 \\
$\begin{array}{l}\text { Daily wt gain, } \\
\text { g/b }\end{array}$ & $36.57^{\mathrm{a}}$ & $36.11^{\mathrm{a}}$ & $35.00^{\mathrm{a}}$ & $34.52^{\mathrm{a}}$ & $28.79^{\mathrm{b}}$ & 1.26 \\
$\begin{array}{l}\text { Total feed } \\
\text { intake, g/b }\end{array}$ & $4307.24^{\mathrm{b}}$ & $4102.84^{\mathrm{bc}}$ & $4585.00^{\mathrm{ab}}$ & $4321.52^{\mathrm{b}}$ & $4723.88^{\mathrm{a}}$ & 135.26 \\
$\begin{array}{l}\text { Daily feed } \\
\text { intake, g/b }\end{array}$ & $76.92^{\mathrm{b}}$ & $73.27^{\mathrm{bc}}$ & $81.88^{\mathrm{ab}}$ & $77.17^{\mathrm{b}}$ & $84.36^{\mathrm{a}}$ & 2.42 \\
FCR & $2.10^{\mathrm{a}}$ & $2.03^{\mathrm{a}}$ & $2.34^{\mathrm{a}}$ & $2.22^{\mathrm{a}}$ & $2.93^{\mathrm{b}}$ & 0.25 \\
\hline
\end{tabular}

$\mathrm{a}, \mathrm{b}, \mathrm{c}=$ Means in the same row bearing different superscripts differ significantly $(\mathrm{P}<0.05)$. $\mathrm{CRC}=$ camel rumen content

\section{Carcass characteristics}

The results of carcass characteristics and internal organs weight are presented in Tables 4 and 5. Final live weight, carcass weight and dressing percent were significantly $(\mathrm{P}<0.05)$ lower in birds fed diet $20 \% \mathrm{CRC}$ compared to birds fed other diets. Birds fed $10 \%$ CRC diet had the highest carcass weight and dressing percent. The primal cuts (the breast, thigh and back) expressed as percentage of dressed weight of experimental birds were significantly $(\mathrm{P}<0.05)$ affected by dietary treatments. Birds fed $20 \%$ CRC diet had similar weight of breast as birds fed the control diet. There were no significant $\quad(\mathrm{P}<0.05) \quad$ differences among treatments for organs weights such as heart, kidney and gizzard and this implies that there were no abnormalities or pathological lesions in these organs.
(4) observed insignificant differences in the organs weight of broiler finishers fed fermented bovine blood and rumen digesta. The intestine length and weight significantly $(\mathrm{P}<0.05)$ increased as the level of CRC increased in the diets. The linear increase in the weights of the intestine across the treatments may be due to their involvement in the digestion process. The weight of liver was significantly $(\mathrm{P}<0.05)$ higher in birds fed 20 $\%$ CRC diet compared to other treatments. The higher value of liver as observed in $20 \%$ CRC could be as a result of anti-nutritional factors in the feed that produces toxicity causing inflammation of and friable liver. $(17,18)$ reported that higher values of organs probably indicate hypertrophy. In any case, it was observed that the values of all the parameters investigated were within the values reported for healthy poultry birds of similar age $(13,19$, 20).

Table 4. Carcass Characteristics of Broilers fed Graded Levels of camel rumen content (CRC)

\begin{tabular}{|c|c|c|c|c|c|c|}
\hline Parameters & 0\% CRC & $5 \%$ CRC & $10 \% \mathrm{CRC}$ & $15 \%$ CRC & $20 \%$ CRC & SEM \\
\hline $\begin{array}{ll}\text { Final live } \\
\text { weight, g }\end{array}$ & $2274.00^{\mathrm{a}}$ & $2238.00^{\mathrm{a}}$ & $2278.33^{\mathrm{a}}$ & $2203.67^{\mathrm{a}}$ & $2112.33^{b}$ & 41.79 \\
\hline $\begin{array}{l}\text { Dressed } \\
\text { weight, } g\end{array}$ & $2030.00^{\mathrm{a}}$ & $2017.00^{\mathrm{a}}$ & $2041.00^{\mathrm{a}}$ & $1945.00^{\mathrm{ab}}$ & $1887.33^{\mathrm{b}}$ & 48.03 \\
\hline $\begin{array}{l}\text { Dressing } \\
\text { Percentage, \% }\end{array}$ & $73.13^{\mathrm{ab}}$ & $72.17^{\mathrm{ab}}$ & $76.37^{\mathrm{a}}$ & $70.22^{\mathrm{ab}}$ & $69.85^{\mathrm{b}}$ & 3.24 \\
\hline $\begin{array}{l}\text { Carcass } \\
\text { weight, } g\end{array}$ & $1663.33^{\mathrm{ab}}$ & $1616.67^{\mathrm{ab}}$ & $1733.33^{a}$ & $1571.67^{b}$ & $1495.00^{\mathrm{b}}$ & 64.45 \\
\hline $\begin{array}{l}\text { Breast weight, } \\
\%\end{array}$ & $22.34^{\mathrm{a}}$ & $18.89^{\mathrm{b}}$ & $18.23^{\mathrm{b}}$ & $18.42^{\mathrm{b}}$ & $20.63^{\mathrm{ab}}$ & 1.37 \\
\hline $\begin{array}{l}\text { Thigh weight, } \\
\%\end{array}$ & $25.81^{\mathrm{a}}$ & $22.93^{\mathrm{b}}$ & $22.77^{\mathrm{b}}$ & $21.41^{\mathrm{c}}$ & $23.84^{\mathrm{ab}}$ & 1.06 \\
\hline $\begin{array}{l}\text { Back weight, } \\
\%\end{array}$ & $16.81^{\mathrm{a}}$ & $15.86^{\mathrm{ab}}$ & $16.53^{\mathrm{ab}}$ & $15.99^{\mathrm{ab}}$ & $15.54^{\mathrm{b}}$ & 0.51 \\
\hline $\begin{array}{l}\text { Heart weight, } \\
\%\end{array}$ & 0.50 & 0.52 & 0.53 & 0.53 & 0.55 & 0.06 \\
\hline
\end{tabular}

$\mathrm{a}, \mathrm{b}, \mathrm{c}=$ Means in the same row bearing different superscripts differ significantly $(\mathrm{P}<0.05) . \mathrm{CRC}=$ camel rumen content

Haematological parameters and differential counts of broiler finishers fed graded levels of camel rumen content (CRC)

The haematological parameters and differential count are shown on Table 6. Changes in haematological parameters are of value in assessing the responses of animals to various physiological and disease conditions (7, 21, 22). Changes in haematological parameters are often used to determine stresses due to 
nutrition and other factors (23). Results obtained from the packed cell volume (PCV), Red blood cell (RBC) and white blood cell (WBC) of the broiler chickens were not significantly $(\mathrm{P}>0.05)$ different among the treatment groups. The values fall within the normal range for healthy broiler chickens reported by $(24,25,26)$. The haemoglobin concentration $(\mathrm{Hb})$ were significantly $(\mathrm{P}<0.05)$ different among the treatment groups. Birds fed $0 \%$ CRC, $10 \%$ CRC, $15 \%$ CRC and 20 $\%$ CRC diets had similar values that were superior to birds fed $5 \% \mathrm{CRC}$ diet. This result is similar to the report of (4) who fed graded levels of bovine rumen content in broiler diets. Mean corpuscular volume (MCV) and mean
MAKINDE O. J., et al. corpuscular haemoglobin $(\mathrm{MCH})$ were not significantly affected $(\mathrm{P}<0.05)$ by the dietary treatments. Mean corpuscular haemoglobin concentration (MCHC) was significantly $(\mathrm{P}<0.05)$ different across the treatment groups. The MCHC for 0\% CRC, 10\% CRC, 15\% CRC and 20\% CRC were similar and higher than 5\% CRC. The values of MCV, MCH and MCHC observed in this study are within the normal range reported by $(24,27)$. The MCV, $\mathrm{MCH}$ and $\mathrm{MCHC}$ are derived from red blood cells, haemoglobin, packed cell volume contents and concentration and they are readily used in the assessment of nutritional status of the chicken as a result of the feed ingested (28).

Table 5. Organs Weight of Broilers fed Graded Levels of camel rumen content (CRC)

\begin{tabular}{lllllll}
\hline Parameters & $\mathbf{0 \%}$ CRC & $\mathbf{5 \%}$ CRC & $\mathbf{1 0 \%}$ CRC & 15\% CRC & $\mathbf{2 0 \%}$ CRC & SEM \\
\hline $\begin{array}{l}\text { Liver weight, } \\
\%\end{array}$ & $1.66^{\mathrm{b}}$ & $1.69^{\mathrm{b}}$ & $1.77^{\mathrm{b}}$ & $1.80^{\mathrm{b}}$ & $2.11^{\mathrm{a}}$ & 0.14 \\
$\begin{array}{l}\text { Kidney weight, } \\
\%\end{array}$ & 0.50 & 0.49 & 0.52 & 0.54 & 0.56 & 0.06 \\
$\begin{array}{l}\text { Gizzard } \\
\text { weight, \% }\end{array}$ & 1.91 & 1.93 & 2.18 & 2.13 & 2.20 & 0.20 \\
$\begin{array}{l}\text { Intestine } \\
\text { weight, g }\end{array}$ & $4.10^{\mathrm{b}}$ & $3.86^{\mathrm{b}}$ & $3.96^{\mathrm{b}}$ & $4.97^{\mathrm{a}}$ & $5.28^{\mathrm{a}}$ & 0.36 \\
$\begin{array}{l}\text { Intestine } \\
\text { length, cm }\end{array}$ & $9.57^{\mathrm{c}}$ & $10.45^{\mathrm{b}}$ & $10.45^{\mathrm{b}}$ & $11.07^{\mathrm{ab}}$ & $11.92^{\mathrm{a}}$ & 0.49 \\
\hline
\end{tabular}

$\mathrm{a}, \mathrm{b}, \mathrm{c}=$ Means in the same row bearing different superscripts differ significantly $(\mathrm{P}<0.05)$. CRC $=$ camel rumen content

Table 6. Haematological parameters of broiler finisher fed graded levels of camel rumen content $(C R C)$

\begin{tabular}{|c|c|c|c|c|c|c|}
\hline Parameters & 0\% CRC & $5 \%$ CRC & $10 \% \mathrm{CRC}$ & $15 \% \mathrm{CRC}$ & $20 \%$ CRC & SEM \\
\hline PCV (\%) & 43.50 & 42.50 & 43.25 & 43.00 & 43.50 & $1.27^{\mathrm{NS}}$ \\
\hline $\operatorname{RBC}\left(\mathrm{X} 10^{6} / \mathrm{mm}^{3}\right)$ & 4.03 & 4.03 & 4.06 & 3.77 & 3.98 & $0.16^{\mathrm{NS}}$ \\
\hline $\mathrm{WBC}\left(\mathrm{X} 10^{3} / \mathrm{mm}^{3}\right)$ & 4.19 & 4.16 & 4.30 & 4.25 & 4.15 & $0.04^{\mathrm{NS}}$ \\
\hline $\mathrm{Hb}(\mathrm{g} / 100 \mathrm{ml})$ & $12.23^{\mathrm{a}}$ & $11.13^{\mathrm{b}}$ & $11.6^{\mathrm{ab}}$ & $11.48^{\mathrm{ab}}$ & $11.58^{\mathrm{ab}}$ & $0.44 *$ \\
\hline $\mathrm{MCV}(\mathrm{f} 1)$ & 10.65 & 10.57 & 10.65 & 10.82 & 11.20 & $0.36^{\mathrm{NS}}$ \\
\hline $\mathrm{MCH}(\mathrm{pg})$ & 29.90 & 27.68 & 28.74 & 28.88 & 29.14 & $1.09^{\mathrm{NS}}$ \\
\hline $\operatorname{MCHC}(\%)$ & $28.12^{\mathrm{a}}$ & $26.17^{b}$ & $26.99^{\mathrm{ab}}$ & $26.80^{\mathrm{ab}}$ & $26.61^{\mathrm{ab}}$ & $0.73 *$ \\
\hline \multicolumn{7}{|c|}{ Deferential counts (\%) } \\
\hline Basophils & 0.10 & 0.25 & 0.25 & 0.10 & 0.25 & $0.27^{\mathrm{NS}}$ \\
\hline Eosinophils & $7.00^{\mathrm{b}}$ & $7.50^{\mathrm{ab}}$ & $8.75^{\mathrm{a}}$ & $7.00^{\mathrm{b}}$ & $7.50^{\mathrm{ab}}$ & $0.65 *$ \\
\hline Heterophils & $34.00^{\mathrm{ab}}$ & $33.50^{\mathrm{b}}$ & $35.75^{\mathrm{a}}$ & $35.50^{\mathrm{a}}$ & $34.00^{\mathrm{ab}}$ & $0.91 *$ \\
\hline Monocytes & 7.75 & 7.25 & 8.50 & 8.00 & 7.00 & $0.79^{\mathrm{NS}}$ \\
\hline Lymphocytes & $50.75^{\mathrm{ab}}$ & $50.50^{\mathrm{a}}$ & $47.25^{\mathrm{b}}$ & $49.00^{\mathrm{ab}}$ & $51.75^{\mathrm{a}}$ & $1.61 *$ \\
\hline
\end{tabular}

${ }^{a, b}$ Means in the same row bearing different superscripts differ significantly $(\mathrm{P}<0.05)$. SEM= Standard error of mean. $\mathrm{CRC}=$ camel rumen content. $\mathrm{PCV}=$ Packed Cell volume. $\mathrm{RBC}=$ Red blood cell. $\mathrm{WBC}=$ White blood cell. $\mathrm{Hb}=$ Haemoglobin. $\mathrm{MCV}=$ Mean corpuscular volume $\mathrm{MCH}=$ Mean corpuscular haemoglobin. $\mathrm{MCHC}=$ Mean corpuscular haemoglobin concentration

\section{Differential Counts (\%)}

The differential counts (\%) are divided into granulocytes which are nucleated white blood cells and comprise of (basophils, eosinophils and heterophils) and agronulocytes which are nucleated white blood cells all comprised of monocytes and lymphocytes. These parameters are associated with body defence mechanism. The basophils and monocytes were not significantly different $(\mathrm{P}<0.05)$ across the treatment groups. The values were similar and fall within the normal range for healthy chicken as reported by (25). Eosinophils, heterophils and lymphocytes were significantly 
$(\mathrm{P}>0.05)$ affected by the dietary treatments. The heterophils of birds fed $0 \%$ CRC, 10 $\%$ CRC, $15 \%$ CRC and $20 \%$ CRC were higher than birds fed $5 \%$ CRC diet. The lymphocytes was significantly $(\mathrm{P}<0.05)$ higher in birds fed 0 $\%$ CRC, $5 \%$ CRC, $15 \%$ CRC and $20 \%$ CRC than birds fed $10 \% \mathrm{CRC}$ diet. These results fall within the normal range of healthy chicken reported by (27) indicating that the diets fed had no harmful effect on the health status of the birds.

\section{CONCLUSION}

The study indicates the potential of camel rumen content (CRC) in the diet of broilers. The result of this study showed that up to $15 \%$ CRC can be included in the diet of broilers to replace maize and groundnut cake. Beyond this level, growth parameters may be affected as observed in this study.

\section{REFERENCES}

1. Ajala, M.K. and Alli-Balogun, J.K., Economics of rabbit production in Zaria, Kaduna State, Nigeria. Trop. J. Anim. Sci. Vol. 7(1): 1-10, 2004.

2. Abouheif, M.A., Kraidees, M.S. and AlSelbood, B.A., The utilization of rumen content-barley meal in the diets of growing lambs. Asian-Australasian Journal of Animal Science, 12(8), 1234-1240, 1999.

3. McDonald, P., Edwards, R. A. and Greenhalgh, J. F. D., Animal nutrition. Evaluation of energy contents of foods. $5^{\text {th }}$ Ed. ELBS Longman Group Ltd. London. Pp. 269, 2002.

4. Esonu, B.O., Azubuike, J.C., Udedibie, A.B.I., Emenalom, O.O., Iwuji, T.C. and Odoemenam, V., Evaluation of the nutritive value of mixture of fermented bovine blood and rumen digesta for broiler finisher. Journal of Natural Sciences Research, 4(1), 1-8. 2011.

5. Alaku, S.O., Influence of season in bull weight and body weight at 3-12 months Wadara calves in sahel region of North East Nigeria. Review Animal Production. 18 (1):23-32, 1983.

6. Ugherughe, P.O. and Ekejolum, P.A., Pasture and Rangeland potentials. Annals of Borno 3:179-192, 1986.

7. Schalm, O. W., Jain, N. C. and Carol, E. J., Veterinery haematology. $3^{\text {rd }}$ lea and Febiger, Philadeiphia, USA pp. 809, 1975.

8. Jain, N.C., Veterinary haematology $4^{\text {th }}$ ed. Lea - Febiger Publishers Philadelphia pp. $153-159,1986$.

9. AOAC (Association of Official Analytical Chemists), Official Method of Analysis of the AOAC (W.Horwitz Editor) Eighteenth Edition. Washighton D.C, USA. 2006.

10.SAS. User's guide: Statistics. Version 12.0. SAS Institute, Inc. Cary. NC, USA, 2008.

11. White, E.P. and Wadak, I., Evaluation of rumen content on the growth performance of weaner rabbits. Proc. 7th Ann. Conf. Anim. Sci Ass. of Nig. (ASAN). Sept. $16-$ 19, University of Agric. Abeokuta, Nigeria, pp. $143-146,2002$.

12.Awesu, R. J., Bangboje, A. M., Oduguwa, O. O., Fanimo, A. O. and Oguntona, E. B. Utilization of rice milling waste for cockerel finishers. Proceedings of $25^{\text {th }}$ Annual conference of Nigeria Society for Animal Production, 19-23 ${ }^{\text {rd }}$ March, Umudike, 2000.

13.Makinde, O.J., Enyigwe, P.C., Babajide, S.E., Atsumbe, J.A., Ibe, E.A. and Samuel, I. Growth performance and carcass characteristics of finisher broilers fed rice offal based diets supplemented with exogenous enzyme. Greener Journal of Agricultural Sciences 4 (4): 144-149, 2014.

14. Atuahene, C.C., Donkoh, A. and NkansahDarko, P., Effects of raw cotton seed meal on the certain blood parameters of broiler chickens. Journal of Animal Production Research, 6:107-133, 1986.

15.Gwayo, G. J., Adebola, I. A., Egbo, M. L. and Doma, U. D., The effects of varying levels of dietary goat rumen content on the performance of broilers chicken, proc. $11^{\text {th }}$ Ann. Conf. Sci. of Nig. (ASAN) 2006 Sept. $18^{\text {th }}-21^{\text {st }}$, I. A. R. and T Ibadan, Nigeria. Pp. 104-107, 2006.

16.Makinde, A.O., Sonaiya, B. and Adeyeye, S., Conversion of abattoir wastes into livestock feed: Chemical composition of sun-dried rumen content blood meal and its effect on performance of broiler chickens. A paper presented at the Conference on International Research on Food Security, Natural Resource Management and Rural Development. University of Hohenheim, October 7-9, Tropentag, 2008.

17.Koong, L.J., Farcell, C.C., Nienata, S.A. (1985). Assessment of Interrelationship among Levels of Intake and Production, Organ Size and Fasting Heat Production in Animals. J. Nutr., 115: 1383-1390.

18.Bond, D.N., Whicher, J.T. and Lee, K.E., In: Recent Advances of Research in Antinutritional Factors in Legumes Seeds. Edited by Husinan J, Vander Poel AFB and Linear IE, Pudoc Wagennigen. pp. 285-296, 1989.

19.Olomu, J.M., Monogastric Animal Nutrition, Principles and Practice. Jackem 
MAKINDE O. J., et al.

Publications, Benin City, Nigeria pp. 69104., 2011.

20.Oluyemi, J.A. and Robert, FA., Poultry production in warm wet climate $\left(2^{\text {nd }} E d n\right)$. Spectrum books Ltd. Ibadan Nigeria, 2000.

21. Yadav, S. P., Kundu, A., Ahiawat, S. P. S., Senani, S., Chatter-Jee, R. M., Saha, S. K., Bharati, D., Kumar, S. J. and Sunder, J., Haematological parameters of indigenous goats of Andaman. Indian Veterinary Journal, 79:665-667, 2002.

22.Khan, T. A. and Zafar, F., Haematological study in response tovarious doses of estrogen in broiler production. Int. J. Poult. Sci.,40(10):748-751, 2005.

23.Afolabi, K. D., Akinsoyini, A. O., Olajide, R. and Akinleye, S. B., Haematological parameters of the Nigerian local grower chickens fed varying dietary levels of palm kernel cake. Proc. of the $35^{\text {th }}$ Annual Conf. of the Nig. Soc. for Anim. Prod., 247, 2010.

24.Anon, L., Guide to the care and use of Experimental Animal. Vol.1. Canadian Council of Animal care, Ottawa, Ontario, Canada. Pp.85-90, 1980.
25.Campbell, J.R., Keneally, M.D. and Campbell, K.L., Animal Sciences. McGrawHill Companies, New York. Pp 187-372, 2003.

26.Abubakar, M.M. and Yusuf, A.O., Effectiveness of rumen content in poultry rations. Proceedings. $16^{\text {th }}$ Annual Conference of Nigerian Society of Animal Production, Sokoto. Pg 78, 1991.

27.Igene, F.U., Biochemical, Nutritional and Physiochemical characteristics of differently processed winged bean seeds. Ph.D. Thesis, Department of Animal Science Ambrose Ali University, Ekpoma, Edo state, Nigeria, 1999.

28. Ojebiyi, O. O., Farinu, G. O., Babatunde, G. M. and Moronfolu, O. O., Study of some haematological attributes of weaned rabbits fed graded levels of sun dried cassava feel, blood meal mixture. Proceeding of 32th Annual Conference of Nigeria Society of Animal Production (NSAP), March $18^{\text {th }}$ $21^{\text {st }}$, University of Calabar, Nigeria. Pp.213-216. 2007. 